\title{
Will our dreams ever come true: treatment options for patients with HAM/TSP in 10 years
}

Cynthia Pise-Masison

From 16th International Conference on Human Retroviruses: HTLV and Related Viruses

Montreal, Canada. 26-30 June 2013

No abstract submitted.

Published: 7 January 2014

doi:10.1186/1742-4690-11-S1-027

Cite this article as: Pise-Masison: Will our dreams ever come true:

treatment options for patients with HAM/TSP in 10 years. Retrovirology

2014 11(Suppl 1):O27.

Submit your next manuscript to BioMed Central and take full advantage of:

- Convenient online submission

- Thorough peer review

- No space constraints or color figure charges

- Immediate publication on acceptance

- Inclusion in PubMed, CAS, Scopus and Google Scholar

- Research which is freely available for redistribution

Submit your manuscript at www.biomedcentral.com/submit
C Biomed Central 